- Note-

\title{
Preparation of Poly ( $N$-Ether Group Substituted Pyrrole) Film-Coated Electrode Incorporating Microparticle Metals
}

\author{
Nobuhiro TAKANO*, Masahito NAKABAYASHI and Noboru TAKENO
}

\section{INTRODUCTION}

Recently the electrically conducting polymers having polyether chain have been attracted interest, because these polymers are expected for applications in ion-selective electrodes, membranes and ionic conductor of batteries ${ }^{1)}$. On the other hand, metal particles incorporated in the polymer-modified electrodes have been recognized to have potential applications in electrocatalytic reaction ${ }^{2)}$. We have previously reported the palladium microparticles incorporated poly $(N$ linear alkyl substituted pyrrole) film electrodes for electrocatalytic hydrogenation ${ }^{3}$ ). The introduction of ionic conductor into matrix is required to improve the ability of polymer electrode in electrocatalytic hydrogenation. We report herein the preparation and characterization of poly ( $N$-ether group substituted pyrrole) film electrodes ( $2 a$ and $2 b$ ) incorporating precious metals such as $\mathrm{Pt}, \mathrm{Pd}$, and $\mathrm{Au}$.

\section{EXPERIMENTAL}

As shown in Scheme 1 the monomers, ether group substituted pyrrole $1 \mathbf{a}$ and $\mathbf{1 b}$ were prepared by the conventional methods. 1a: 90 ${ }^{\circ} \mathrm{C} / 1$ torr (Kugelrolle), ${ }^{1} \mathrm{H}$ NMR(270 $\mathrm{MHz}$, $\mathrm{CDCl}_{3}$-DMSO-d $\left.d_{6}\right) \delta 3.20(\mathrm{~s}, 1 \mathrm{H},-\mathrm{OH}), 3.51(\mathrm{t}$, $\left.2 \mathrm{H}, J=5 \mathrm{~Hz},-\mathrm{CH}_{2} \mathrm{OH}\right), 3.65(\mathrm{t}, 2 \mathrm{H}, J=5 \mathrm{~Hz}$, $\left.-\mathrm{CH}_{2} \mathrm{O}-\right), 3.74\left(\mathrm{t}, 2 \mathrm{H}, J=6 \mathrm{~Hz},-\mathrm{CH}_{2} \mathrm{O}-\right), 4.06(\mathrm{t}$, $\left.2 \mathrm{H}, J=5 \mathrm{~Hz},>\mathrm{NCH}_{2}-\right), 6.11(\mathrm{t}, 2 \mathrm{H}, J=2 \mathrm{~Hz}$, Pyrrole), 6.71 (t, $2 \mathrm{H}, J=2 \mathrm{~Hz}$, Pyrrole). IR (neat) $3415,2927,2873,1500,1439,1356,1286$, $1128,1092,1070,731,619 \mathrm{~cm}^{-1} \cdot 1 \mathrm{~b}: 130^{\circ} \mathrm{C}$ / 2 torr (Kugelrolle), ${ }^{1} \mathrm{H}$ NMR (270 $\mathrm{MHz}$, $\left.\mathrm{CDCl}_{3}-\mathrm{DMSO}-d_{6}\right) \delta 3.07(\mathrm{~s}, 1 \mathrm{H},-\mathrm{OH})$,

Department of Applied Chemistry, Muroran Institute of Technology (27-1 Mizumoto-cho, Muroran 050, Japan)

Key Words: Metal Microparticles Incorporation, Polymer Film Electrode
$3.52 \sim 3.55\left(\mathrm{~m}, 6 \mathrm{H},>\mathrm{NCH}_{2} \mathrm{CH}_{2} \mathrm{O}-,-\mathrm{OCH}_{2}-\right.$ $\left.\mathrm{CH}_{2} \mathrm{OH}\right), 3.58 \sim 3.73\left(\mathrm{~m}, 4 \mathrm{H},-\mathrm{OCH}_{2} \mathrm{CH}_{2} \mathrm{O}-\right)$, $4.03\left(\mathrm{t}, 2 \mathrm{H}, J=5.6,>\mathrm{NCH}_{2}-\right), 6.10(\mathrm{t}, 2 \mathrm{H}$, $J=2 \mathrm{~Hz}$, Pyrrole), 6.68 (t, $2 \mathrm{H}, J=2 \mathrm{~Hz}$, Pyrrole). IR(neat) $3433,2873,1500,1456,1352,1286$, $1120,1090,729,619 \mathrm{~cm}^{-1}$.
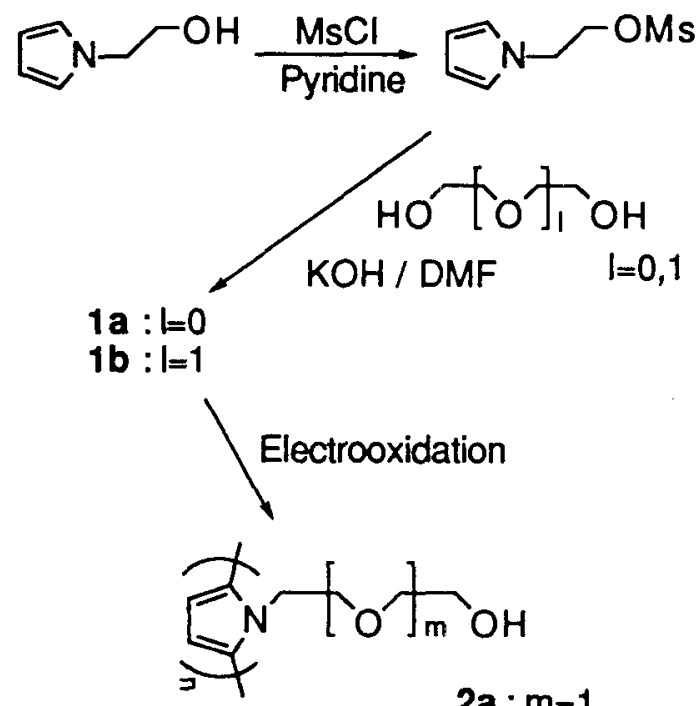

$2 a: m=1$

$2 b: m=2$

Scheme 1

The coating of polymer film $2 \mathrm{a}$ and $2 \mathrm{~b}$ on glassy carbon disk (Area : $0.071 \mathrm{~cm}^{2}$ ) was carried out by potential sweep between 0 and $1.1 \mathrm{~V}$ vs. SCE (saturated calomel electrode) or controlledpotential electrolysis at $1.1 \mathrm{~V}$ in $\mathrm{CH}_{3} \mathrm{C} \mathrm{N}$ containing $10 \mathrm{mmol} \mathrm{dm}^{-3}$ monomers and 0.1 mol dm${ }^{-3} \mathrm{Bu}_{4} \mathrm{NBF}_{4}$. The incorporation of metal in films was conducted according to the previously reported procedures ${ }^{3)}$. The quantity of palladium metal in film was determined by the electroreduction method in $0.1 \mathrm{~mol} \mathrm{dm}^{-3} \mathrm{KCl}$ 
solution. The current-voltage curves were measured by a linear sweep potential method.

\section{RESULTS AND DISCUSSION}

Figure 1 shows the cyclic voltammograms of prepared monomers, $N$ - (5-hydroxy, 3-oxapentyl) pyrrole $1 \mathrm{a}$ and $N$-(8-hydroxy, 3, 6-dioxaoctyl ) pyrrole $1 \mathrm{~b}$ in $\mathrm{CH}_{3} \mathrm{CN}$ containing $\mathrm{Bu}_{4} \mathrm{NBF}_{4}$. These voltammograms show gradual increase in one redox peak couple at ca. $0.5 \mathrm{~V}$ in the successive cycles, as already observed for poly [N-(5-hydroxypentyl) pyrrole] film (PHPy) ${ }^{3)}$. These couples corresponded to the anion $\mathrm{BF}_{4}{ }^{-}$ doping-dedoping process. The resulting electropolymerized films exhibited considerable stability with slight decrease of peak current when cyclic potential sweep experiments were performed in the potential range of 0 to $0.8 \mathrm{~V}$ in an electrolyte solution free of monomer. The incorporation of catalytic metals into the polymer films which were prepared by the controlled-potential electrolysis method was performed by immersion treatment in a $50 \mathrm{mmol}$ $\mathrm{dm}^{-3} \mathrm{Na}_{2} \mathrm{PdCl}_{4}, \mathrm{~K}_{2} \mathrm{PtCl}_{4}$, and $\mathrm{KAuCl}_{4}$ solution and followed by the electrochemical reduction of permeated anions in films. The catalytic metals were more incorporated in film $2 \mathrm{a}$ than $\mathbf{2 b}$. The amount of palladium metal was less than ca. 10 $\sim 20 \%$ compared with the case of PHPy.

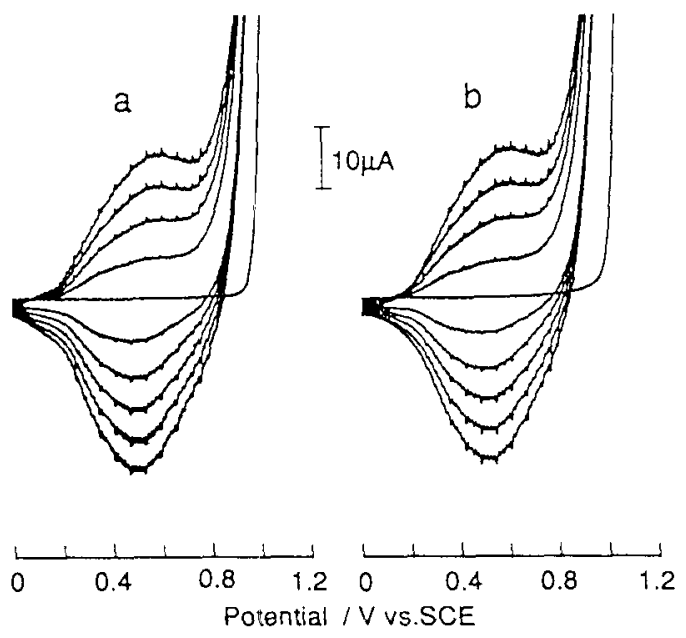

Fig. 1 Cyclic voltammograms of $10 \mathrm{mmol} \mathrm{dm}^{-3}$ la (a) and $1 \mathrm{~b}$ (b) on glassy carbon disk electrode in $0.1 \mathrm{~mol} \mathrm{dm}{ }^{-3} \mathrm{Bu}_{4} \mathrm{NBF}_{4}-\mathrm{CH}_{3} \mathrm{CN}$ solution. Scan rate $100 \mathrm{mV} \mathrm{s}^{-1}$.
The amount of metals incorporated in film $\mathbf{2 b}$, which was formed under the polymerization electricity $Q=0.14 \mathrm{C} \mathrm{cm}^{-2}$, increased in order of $\mathrm{Au}\left(14 \mu \mathrm{g} \mathrm{cm}^{-2}\right), \mathrm{Pd}\left(7.0 \mu \mathrm{g} \mathrm{cm}^{-2}\right)$, and $\mathrm{Pt}(4.4$ $\left.\mu \mathrm{g} \mathrm{cm}^{-2}\right)$ and was proportional to the thickness of films. These behaviors show that the ether oxygen atoms in chains dose not greatly contribute to the incorporation of anions. The penetrations of the metal chloride anions, $\mathrm{PdCl}_{4}{ }^{2-}, \mathrm{PtCl}_{4}{ }^{2-}$, and $\mathrm{AuCl}_{4}{ }^{-}$into film may be interfered by the electron-repulsion between them and lone paired electrons of oxygen atoms.

As shown in Figure 2, when the currentvoltage curves for metals incorporated polymer film $2 \mathrm{~b}$ electrode in a $0.1 \mathrm{~mol} \mathrm{dm} \mathrm{dm}^{-3} \mathrm{HClO}_{4}$ aqueous solution were measured, steep rise in cathodic currents based on hydrogen evolution were observed at $c a .-0.4 \sim-0.5 \mathrm{~V}$. The potentials of the $\mathrm{H}^{+}$reduction to $\mathrm{H}_{2}$ for catalytic film electrodes were shifted in order of $\mathrm{Pt}, \mathrm{Pd}$, and $\mathrm{Au}$ to cathodic potential side. This order agreed with that of hydrogen overvoltage of metals in aqueous solution. It is of interest that using these catalytic film electrodes $\mathrm{H}^{+}$was

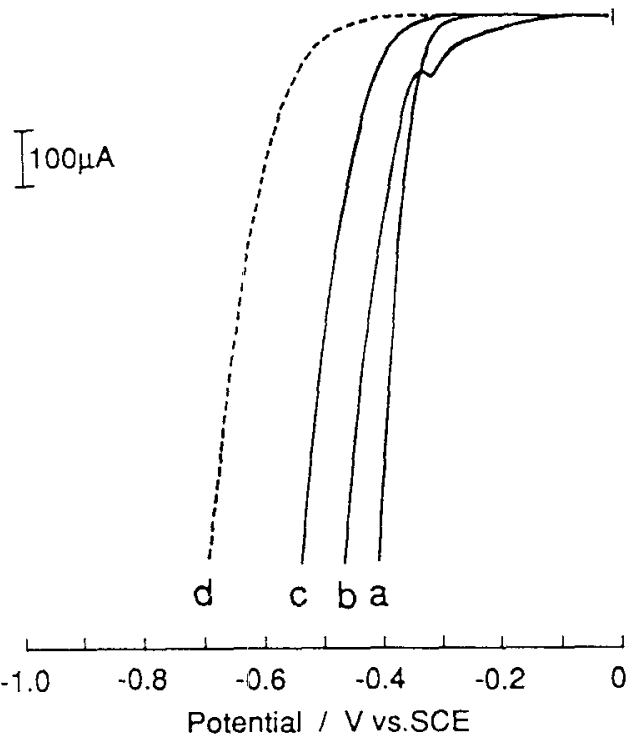

Fig. 2 Cathodic current-voltage curves for hydrogen evolution of metal incorporated polymer film $2 \mathrm{~b}$ electrodes in $0.1 \mathrm{~mol} \mathrm{dm}^{-3} \mathrm{HClO}_{4}$ solution. Scan rate $20 \mathrm{mV} \mathrm{s}^{-1}$. a) : $\mathrm{Pt}\left(4.4 \mu \mathrm{g} \mathrm{cm}^{-2}\right)$, b) : Pd $\left(7.0 \mu \mathrm{g} \mathrm{cm}{ }^{-2}\right)$, c) : Au $\left(14 \mu \mathrm{g} \mathrm{cm}^{-2}\right)$ incorporated film electrode, $d)$ : film electrode. 
reduced at lower potential in spite of the metals were less incorporated in the film.

The current-voltage curves for palladium metal incorporated polymer film $2 \mathbf{a}, \mathbf{2 b}$, and

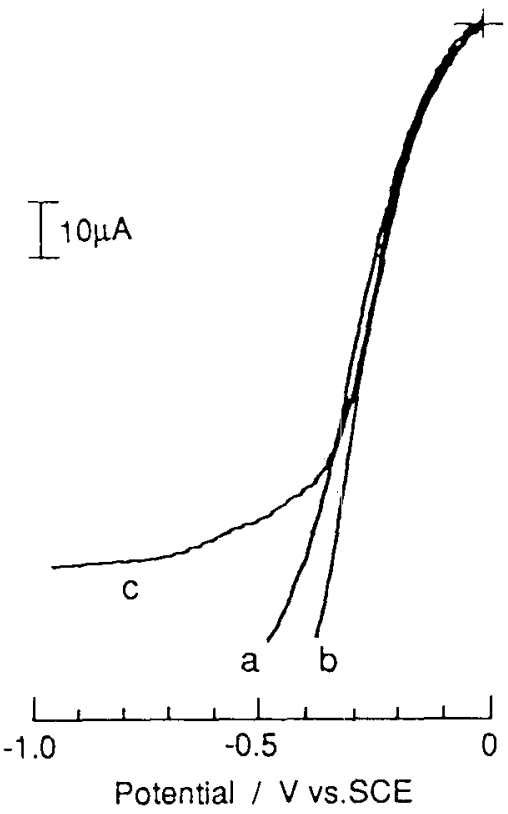

Fig. 3 Cathodic current-voltage curves for hydrogen evolution of $\mathrm{Pd}$ metal incorporated polymer film electrodes in $0.1 \mathrm{~mol} \mathrm{dm}{ }^{-3} \mathrm{HCl}$ buffer solution $(\mathrm{pH}=1)$ containing $50 \%$ ethanol. Scan rate $100 \mathrm{mV} \mathrm{s}^{-1}$. a) :2a $\left.\left(8.4 \mu \mathrm{g} \mathrm{cm} \mathrm{cm}^{-2}\right), \mathrm{b}\right): 2 \mathrm{~b}(7.0$ $\left.\left.\mu \mathrm{g} \mathrm{cm}^{-2}\right), \mathrm{c}\right):$ PHPy $\left(9.3 \mu \mathrm{g} \mathrm{cm}^{-2}\right)$ film electrode.
PHPy electrodes in $0.1 \mathrm{~mol} \mathrm{dm} \mathrm{dm}^{-3} \mathrm{HCl}$ buffer solution $(\mathrm{pH}=1)$ containing $50 \%$ ethanol are shown in Fig. 3. The current-voltage characteristics similar to those measured in the $\mathrm{HClO}_{4}$ solution were observed. The film $2 \mathrm{a}$ and 2b electrodes showed highly catalytic activity compared with PHPy. This result suggests that the migration of proton as hydrogen source is enhanced by the presence of ethereal chains in matrix film.

Further research is in progress in our laboratories for development of an electrocatalytic hydrogenation for organic compounds using these catalytic film electrodes.

This work was supported by Grant-in-Aid for Scientific Research on Priority Area (No.236) from the Ministry of Education, Science and Culture of Japan.

\section{REFERENCES}

1) J. Roncali, R.Garreau, D Delabouglise, F. Garnier and M. Lemaire, J. Chem. Soc., Chem. Commun., 1989, 679; J. Roncali, H. K. Youssoufi, R. Garreau, F. Garnier and M. Lemaire, J. Chem. Soc., Chem. Commun., 1990, 414.

2) W-H. Kao and T. Kuwana, J. Am. Chem. Soc., 106, 473 (1984); D.E. Bartak, B. Kazee, K. Shimazu and T.Kuwana Anal. Chem., 58, 2756 (1986); T. Yamada, T. Osa and T. Matsue, Chem. Lett., 1987, 1611.

3) N. Takano, M. Nakabayashi and N. Takeno, Denki Kagaku, 62, 1238 (1994). 